\title{
FORMACIÓN Y USOS \\ DE LOS CONVENTOS EN LA PROVINCIA FRANCISCANA DE MICHOACÁN DURANTE EL VIRREINATO
}

\author{
José Manuel Martínez Aguilar \\ Universidad Michoacana de San Nicolás de Hidalgo
}

U

no de los principales intereses que tenían los reyes católicos y la Iglesia en los territorios conquistados en América era salvar a los naturales de los supuestos "engaños del demonio" e implantar la nueva fe en un campo fértil, así como coadyuvar en la pacificación y conquista militar. Fue a los predicadores mendicantes a quienes se les confió inicialmente la tarea de llevar a cabo la labor evangélica y erradicar las antiguas prácticas religiosas por medio de la evangelización y la implantación de costumbres que los europeos consideraban civilizadas. ${ }^{1}$ Para lograrlo era necesario fundar conventos, templos, capillas de visita y misiones donde se pudiera bautizar, adoctrinar y enseñar diversas artes a los neófitos, así como seminarios donde se formaran nuevos apóstoles.

Fecha de recepción: 7 de octubre de 2019

Fecha de aceptación: 20 de enero de 2020

${ }^{1}$ De fondo los religiosos tenían contemplado poner a disposición de los infieles los medios normales de conversión para formar una Iglesia indiana, lo cual finalmente no se logró por la eventual prohibición de que los indios se ordenaran como sacerdotes. RICARD, La conquista espiritual, p. 21. 
A menudo se cree que los conventos que han llegado hasta nuestros días corresponden a las fechas de fundación que proporcionan las crónicas; sin embargo, se tiene evidencia para afirmar que muchos de ellos fueron reconstruidos en la segunda mitad o a finales del siglo xvi, lo que nos lleva a hacer algunas precisiones. ${ }^{2}$ Aunque parece contradictorio, en los primeros años de la evangelización, cuando la población del occidente de la Nueva España era de millones de indios, se construyeron un puñado de capillas y conventos sumamente modestos, mientras que a fines del mismo siglo, cuando la población había menguado de manera significativa, se levantaron la mayoría de los conventos, más sólidos y mejor construidos; otro puñado de edificios se erigieron en el siguiente siglo o incluso en el XVIII.

Respecto a la actividad constructiva y funcionamiento de los conventos y demás edificios religiosos administrados por los franciscanos en la Nueva España se ha escrito muy poco y sólo unos cuantos autores se han atrevido a establecer una periodización de este fenómeno durante el virreinato. George Kubler dice que la erección de conventos durante el siglo xvi, refiriéndose a todas las órdenes mendicantes, se dio básicamente en dos etapas. A la primera la llama preconventual y, la fija de 1524 a 1546; a la segunda la nombra conventual y la ubica de 1546 a finales del siglo XVI, con una actividad constructiva importante en los años setenta. ${ }^{3}$ Kubler no aborda el resto del periodo virreinal, como sí lo hace Carlos Chanfón, quien propone cuatro etapas más en la formación y funcionamiento de los conventos novohispanos: la primera la fija durante todo el siglo xvi y la llama provisional o de prestado; la segunda la establece entre los siglos XVI y XVII cuando, dice, se dio un crecimiento y producción conventual; la

\footnotetext{
2 En las crónicas franciscanas es común hablar de conventos para referirse por igual a un convento pequeño que a un conjunto conventual compuesto por el convento propiamente dicho, el templo, patio (atrio), capillas posas y demás elementos constructivos.

3 Kubler, Arquitectura mexicana, p. 304.
} 
tercera la sitúa en los siglos XVII y XVIII, en los cuales considera que se puede observar una transformación en los espacios; la cuarta y última la ubica en el siglo XIX, cuando se experimenta una reducción y pérdida espacial de los edificios. ${ }^{4}$ Las etapas que presenta Chanfón, al igual que las de Kubler, no se refieren específicamente a la provincia de Michoacán ni a la orden franciscana, que en este caso es la de nuestro interés.

Basado en las crónicas franciscanas, bibliografía especializada, documentos de archivo y en la observación de los vestigios materiales producidos por encargo de los franciscanos en la provincia de Michoacán, se proponen en este trabajo cinco etapas en la historia de los conventos de la provincia de San Pedro y San Pablo de Michoacán, durante la época virreinal, que corresponden también al proceso de evangelización, adoctrinamiento y administración de la provincia franciscana. Aunque cada uno de los conventos tuvo sus particularidades, se pretende identificar procesos generales con situaciones que compartían, lo que puede ofrecer un panorama general sobre el surgimiento, desarrollo y colapso de la vida de los mismos, y que sirva como base para estudios posteriores.

\section{ETAPA 1. INCURSIÓN O PENETRACIÓN, 1525-1540}

La primera etapa en el proceso de evangelización, adoctrinamiento y actividad constructiva de conventos y capillas de visita en el occidente de la Nueva España, que después se convertiría en la provincia de los Santos Apóstoles de San Pedro y San Pablo de Michoacán, la hemos delimitado desde la llegada de los primeros franciscanos a Tzintzuntzan hasta inicios de 1540. Durante este periodo se dieron los primeros pasos para ir sembrando entre los pueblos de la ribera del lago de Pátzcuaro las primeras capillas y conventos primitivos que servirían más

${ }^{4}$ Chanfón (coord.), Historia de la arquitectura, vol. II, t. II. 
tarde como puntos de irradiación de la religión católica hacia otros asentamientos de la sierra central de Michoacán y posteriormente hacia todas direcciones.

Fue en 1524 cuando llegaron los llamados "doce primeros" franciscanos y comenzaron su labor en los pueblos del Valle de México, Texcoco, Huejotzingo y Tlaxcala, que se convirtieron en los primeros centros de cristianización, ya que desde cada uno de estos puntos se salía a dar atención a los habitantes de los poblados cercanos. Teniendo todos los permisos y comisiones, en 1525 se fundó la custodia del Santo Evangelio, dependiente de la provincia española de San Gabriel, en Extremadura, la cual abarcaba prácticamente toda la Nueva España. Desde ese año, hasta 1536, la provincia de Michoacán estuvo sujeta a la custodia recién fundada y era administrada desde el convento de San Francisco de la ciudad de México. ${ }^{5}$

A finales de 1525 llegó fray Martín de Jesús a Tzintzuntzan, acompañado de fray Antonio Ortiz y fray Andrés de Córdoba, quienes encontraron una gran población nativa con la que empezar a trabajar en la conversión. ${ }^{6}$ Ahí lo primero que hizo fray Martín fue entrevistarse con el Tzintzicha Tangáxoan II -quien ya había sido bautizado en la ciudad de México con el nombre cristiano de Francisco- para pedirle un lugar en dónde edificar una casa y una iglesia. El líder tarasco hospedó a los frailes en su propio palacio y dio órdenes para que se comenzara la obra solicitada por el ministro: "[...] y con el trabajo de los indios de Tzintzuntzan construyeron una iglesia de madera y un monasterio de adobe con celdas techadas de paja, acordes con el ideal franciscano de pobreza. Así se fundó el primer convento

${ }^{5}$ Espinosa, Crónica de la provincia, p. 99; Beaumont, Crónica de Michoacán, t. II, p. 349; WRIGHT, Los franciscanos y su labor, p. 17.

${ }^{6}$ Warren, La conquista de Michoacán, p. 112. 
de Michoacán, con su respectiva capilla, bajo la advocación de Santa Ana. ${ }^{7}$

Desde entonces, esta sede se convirtió en el centro de irradiación de la evangelización en un amplio territorio que tenía, según Espinosa, 360 leguas de longitud y 150 de latitud. La mayoría de capillas o ermitas que funcionaban como visitas -también llamadas misiones, al pertenecer a una custodia que dependía de una provincia- eran avanzadas para ponerse en contacto y predicar entre poblaciones que jamás habían oído sobre el Evangelio. Muchas de ellas podían estar lejos de la sede de la custodia y ser de distintas etnias, algunas nómadas o seminómadas. Las visitas o misiones podían ser de tres tipos básicamente: de ocupación, de penetración y de enlace. Las de ocupación formaban una estrecha red de visitas alrededor de un convento, que era de mayor jerarquía; las de penetración eran conventos -en algunas crónicas son llamados “casas"- en zonas alejadas, de difícil acceso o clima hostil; las de enlace eran una serie de conventos y capillas que, en lugar de estar alrededor de un convento de mayor jerarquía, formaban parte de una línea más o menos directa que ligaba a un grupo y que unía a varios pueblos en una ruta. ${ }^{8}$

Siendo aún dependientes de la custodia del Santo Evangelio, las capillas de visita y los conventos franciscanos de Michoacán, encabezados por el primitivo convento franciscano de Tzintzuntzan, comenzaron a multiplicarse y formar una red misional alrededor del lago de Pátzcuaro: en Cocupao -actual Quiroga-, Santa Fe de la Laguna, San Jerónimo Purenchécuaro, San Andrés Tziróndaro, Erongarícuaro y Pátzcuaro; después en Uruapan, Zacapu, Acámbaro, Zinapécuaro, Charo y Ucareo -estos dos últimos más tarde fueron administrados por los agustinos-,

\footnotetext{
7 Alcalé, La Relación de Michoacán, p. 264; Ramínez, La catedral de Vasco, p. 440.

${ }^{8}$ RICARD, La conquista espiritual, p. 160.
} 
así como los conventos del actual estado de Jalisco: Etzatlán y Zapotlán, entre otras capillas de visita difíciles de precisar.9

Cuando los religiosos llegaban a los pueblos colocaban cruces en los cerros más eminentes, en las plazas, en los barrios y en todas las casas, con las que "ahuyentaban los demonios"10 y se instalaban en los más importantes lugares de adoración o de gobierno para abatir el paganismo de esos sitios y organizar su trabajo apostólico. El corazón de cada poblado era el templo, comúnmente edificado en la parte más alta, con su altar mayor colocado al oriente, mientras el convento se alzaba casi siempre en el costado sur del templo. ${ }^{11}$

Los primeros conventos y capillas eran construidos por los indios de cada pueblo con algunas indicaciones de los frailes, utilizando los materiales y sistemas constructivos de la región: principalmente muros de adobe o piedra, cimientos de piedra, cubiertas de madera y paja, pisos de piedra y madera, y en algunos casos las puertas y ventanas eran enmarcados con elementos de cantería; en la región de la Tierra Caliente los materiales de origen vegetal eran los más empleados. Todos los edificios eran sencillos, pequeños, con espacio suficiente para cubrir al sacerdote de las inclemencias del tiempo y que pudiese celebrar misas y bautizar a los indios. ${ }^{12}$ De aquellos edificios primitivos prácticamente no queda nada.

Ciertamente, el problema básico en los primeros años de la evangelización de la Nueva España era el reducido número de religiosos frente a la gran cantidad de pueblos que tenían

9 "Para erigir una custodia autónoma [...] se requieren al menos 25 hermanos profesos solemnes y 4 guardianías y la fundada esperanza del incremento de la orden.” Estatutos generales de la Orden de Frailes Menores, artículo 116-2. Alcalá, La Relación de Michoacán, p. 264.

10 Espinosa, Crónica de la provincia, p. 81.

11 RicARD, La conquista espiritual, p. 264.

12 Al hablar de los recintos religiosos las crónicas mencionan iglesias, capillas, porciúnculas, ermitas, casas, conventicos, conventos o monasterios, algunas veces refiriéndose a lo mismo. 
que atender. No obstante, ocho o nueve meses después de los llamados "primeros doce", vinieron a ayudarles en la segunda barcada fray Antonio Maldonado, fray Antonio Ortiz, fray Antonio de Herrera, fray Diego de Almonte y unos cuantos de la provincia de San Gabriel, quienes, junto con fray Martín de Jesús, fueron las columnas de la cristiandad en Michoacán. ${ }^{13}$ En el año 1527 llegó otra misión a la Nueva España, parte de la cual pasó a Michoacán. ${ }^{14}$ Dos años después, en 1529, arribaron a tierras michoacanas fray Juan de San Miguel, fray Jerónimo de Alcalá, fray Miguel de Bolonia, fray Juan de Padilla y varios franciscanos más. ${ }^{15}$ Todos ellos, según La Rea, "comenzaron a levantar los estandartes de la fe y a batir los de la idolatría, que tan radicados estaban, destruyendo los templos de sus dioses y erigiendo la primera iglesia, en que se colocó la verdadera imagen de Dios nuestro Señor”. ${ }^{16}$

Los doctrineros tuvieron libertad para moverse en distintas direcciones, pero debían tomar en cuenta el clima, el personal del que podían disponer, los recursos financieros, la manera de reaccionar de los indios y el consentimiento de la corona-aunque rara vez se pedía su autorización de manera directa-. ${ }^{17}$ Además, para evitar una acogida hostil, antes del primer arribo de los misioneros a cualquier poblado, enviaban a un mensajero intérprete a dar aviso a las autoridades para su aprobación y para que tuvieran a bien recibirlos.

Las rutas de evangelización que utilizaron los religiosos se basaban en los acuerdos fijados en los capítulos provinciales, dando prioridad a los pueblos más numerosos o de cierta importancia y, posteriormente, a todos aquellos a donde no hubiese

13 Espinosa, Crónica de la provincia, p. 77; Mendieta, Historia eclesiástica indiana, p. 401.

${ }^{14}$ Espinosa, Crónica de la provincia, p. 81.

15 Alcalá, La Relación de Michoacán, p. 246.

16 La Rea, Crónica de la orden, p. 83.

17 Ricard, La conquista espiritual, pp. 146 y 162. 
llegado "la palabra de Dios". Los caminos que utilizaban para trasladarse de un pueblo a otro solían ser los preexistentes, es decir, se aprovecharon los caminos que los guías nativos conocían y que podían ser difíciles de transitar; en algunos casos el camino entre pueblo y pueblo era a través de montes, barrancas o lagos. Aun siguiendo los caminos conocidos, algunos de los religiosos llegaban a morir por las difíciles jornadas que realizaban, la mala alimentación que tenían, los peligros que enfrentaban en la naturaleza y los ataques de los indígenas de algunas áreas geográficas -por ejemplo, en la Gran Chichimeca.

En los siguientes diez años después de la llegada de fray Martín de Jesús, los franciscanos habían recorrido casi toda la sierra central de Michoacán. Sin embargo, no habían tenido la oportunidad de fundar nuevos conventos y apenas salían a oficiar misa una vez a la semana desde Tzintzuntzan, por lo que se requería del arribo de más religiosos. ${ }^{18} \mathrm{Al}$ irse multiplicando el número de frailes y consolidando su labor, fue necesario ampliar y levantar sus templos y conventos de materia más sólida y permanente. ${ }^{19}$ Con esta multiplicación de edificios se fue tejiendo una red misional que hacía más cercano el contacto con las poblaciones de indios y por tanto se tenía un mejor control de las mismas, no sólo por los religiosos sino por el gobierno español.

El aumento en el número de conventos y ministros religiosos en Michoacán y Jalisco permitió que un territorio amplio al occidente de la Nueva España fuera elevado a custodia, al mismo tiempo que la custodia del Santo Evangelio adquirió la categoría de provincia. De manera oficial, en la bula del 11 de agosto de 1536, el papa Paulo III erigió la diócesis de Michoacán y la custodia de los Santos Apóstoles San Pedro y San Pablo de Michoacán y Jalisco. ${ }^{20} \mathrm{~A}$ partir de entonces, la custodia de Michoacán

${ }^{18}$ LeÓn, Los orígenes del clero, p. 68.

19 Espinosa, Crónica de la provincia, pp. 89-90; Mendieta, Historia eclesiástica, pp. 255-256.

20 Bravo, Historia sucinta de Michoacán, p. 175. 
tuvo jurisdicción propia, pero en los asuntos de relevancia seguía dependiendo de la provincia del Santo Evangelio de México. Su jurisdicción abarcaba el actual estado de Michoacán, Jalisco, Nayarit, Colima, Guanajuato, Querétaro y parte de Guerrero, mientras que hacia el norte, la frontera se encontraba abierta hacia Sinaloa, Zacatecas, Durango, Nuevo León, una fracción de San Luis Potosí y Tamaulipas. Según Espinosa, su extensión era de 360 leguas de longitud por 150 de latitud -aproximadamente $2005.9 \mathrm{~km} \times 835.9 \mathrm{~km}-$; un territorio demasiado amplio para el número de predicadores disponibles. ${ }^{21}$

Por este tiempo, la sede de la custodia seguía siendo el convento de la recién nombrada ciudad de Tzintzuntzan, el único de Michoacán que, representado por los frailes residentes en él, tenía voz y voto en las reuniones capitulares que se efectuaban en el convento franciscano de México, al tener la categoría de guardianía, en la que residían al menos cuatro religiosos, siendo nombrado fray Martín de Jesús el primer custodio. Para entonces, se había levantado un nuevo templo y convento a poca distancia de las construcciones originales..$^{22}$

El 20 de septiembre de 1537, obedeciendo a una cédula real, el virrey Antonio de Mendoza asignó a la ciudad de Tzintzuntzan, o "ciudad de Michoacán", como sede catedralicia.. ${ }^{23}$ Al no aceptar fray Luis de Fuensalida el cargo de obispo de la diócesis de Michoacán, se le confirió tal responsabilidad a don Vasco de Quiroga, quien recibió la bula en la ciudad de México a principios de 1538 e hizo formalmente la toma de posesión el 6 de agosto, en la capilla de Santa Ana. ${ }^{24}$ Es bien conocido que en poco tiempo el obispo mudó la sede diocesana a Pátzcuaro, que por entonces era barrio de Tzintzuntzan, y se llevó consigo a los sacerdotes, autoridades civiles y una parte de la población

\footnotetext{
${ }^{21}$ Espinosa, Crónica de la provincia, p. 111.

22 Warren, La conquista de Michoacán, p. 77.

23 Boletín eclesiástico del Arzobispado de Michoacán, 5 (1897), p. 15.

${ }^{24}$ Martínez, "Los inicios de la evangelización”, p. 100.
} 
de la antigua capital michoacana. ${ }^{25}$ Por estas fechas es cuando se fundan el convento de San Francisco de Pátzcuaro y el hospital de indios de la misma orden.

\section{ETAPA 2. EXPANSIÓN, 1540-1570}

Ya que la población nativa se encontraba de por sí dispersa por todo el occidente de la Nueva España, la disminución de habitantes, resultado de las constantes epidemias, había dejado numerosos asentamientos con poca población o totalmente deshabitados. Ante esta situación, la corona española y los religiosos se dieron cuenta de la dificultad para recaudar los tributos y adoctrinar a los neófitos de manera efectiva, por lo que se vieron en la necesidad de concentrarlos -congregarlos o reducirlos- en pueblos trazados ex profeso. Fue así que desde la década de 1530 los franciscanos llevaron a cabo una serie de congregaciones de población en Michoacán, ${ }^{26}$ mismas que sirvieron de referencia para otras concentraciones ordenadas por el virrey Velasco a partir de 1559, con la indicación de que éstas se hicieran "[...] en traza cerca de las iglesias y monasterios [...] para que vivan en policía cristiana, sin quitarles sus usos y costumbres [...] porque es cierto que, como estaban dispersos por montes, sierras y barrancas, no se podía tener cuenta con el patrimonio de Jesucristo ni con el de vuestra majestad". ${ }^{27}$

En relación con la manera como los franciscanos realizaban las fundaciones, Espinosa señala el siguiente procedimiento: “[...] luego que los tenía congregados, se iniciaba el trazo de calles, plazas y edificios administrativos y la repartición de los lotes; dejando el convento como punto de partida hacia los cuatro puntos cardinales". Después "los instruían en el modo que

\footnotetext{
25 Warren, La conquista de Michoacán, p. 116.

26 Salazar, "Ordenamiento espacial del territorio", p. 169.

27 Gerhard, Geografía histórica, p. 27.
} 
habían de observar en su gobierno, componiendo sus repúblicas y trayendo maestros de todos los oficios para que los aprendiesen y así salieron los tarascos tan grandes oficiales". ${ }^{28}$ Debido a estas congregaciones, un número indeterminado de pueblos fueron eliminados; y para evitar que los congregados regresaran a sus lugares de origen, los templos, ermitas y conventos de los pueblos abandonados eran demolidos y las casas quemadas. ${ }^{29}$

De acuerdo a estas indicaciones, la mayoría de congragaciones implicaron la demolición de los templos, capillas y conventos primitivos y la construcción de edificaciones más sólidas, alrededor de las cuales se distribuían las casas, edificios y espacios públicos. Cuando los frailes llegaban por primera vez a poblados con un número considerable de indios tomaban posesión del lugar haciendo el ritual de fundación, con la consagración de un espacio, la colocación de una cruz y la erección de un sencillo cobertizo a manera de capilla, en tanto se construían edificios más duraderos.

No obstante la minuciosa organización de los frailes, con frecuencia surgían quejas por parte de las autoridades reales y diocesanas respecto a que los mendicantes elegían los sitios con mejor clima y construían conventos muy cercanos unos de otros para su mayor comodidad. ${ }^{30}$ El mismo rey de España emitió una cédula al comisario de la orden de San Francisco de la Nueva España el 23 de agosto de 1538, en la que lo exhortaba a evitar la construcción de conventos en partes no convenientes o muy cercanos con los de otras órdenes o de la suya propia, "para evitar conflictos y que algunas regiones queden sin ministros por concentrarse tantos religiosos en un territorio pequeño". ${ }^{31}$ Un claro ejemplo es el desacuerdo que expresó el obispo Vasco de Quiroga acerca de que se construyera el convento de

28 Espinosa, Crónica de la provincia, p. 125.

29 Castro, Los tarascos y el imperio, p. 86.

30 RICARD, La conquista espiritual, p. 161.

31 Becerril y Cerda (comp.), Catálogo de documentos, p. 55. 
Erongarícuaro, al considerar que era innecesario porque en las cercanías ya existían el de Pátzcuaro y el de Tzintzuntzan. ${ }^{32} \mathrm{El}$ rey Felipe II también se manifestó en el mismo tenor en 1561, asegurando que se ponía poco cuidado a "los monasterios que se hacen, se edifican muy cerca unos de otros, porque tienen fin a poblar en lo bueno, rico y fresco y cerca de esa ciudad de México, y se dejan veinte y treinta leguas los indios sin doctrina, por no querer los religiosos poblar en tierras fragosas y calientes y pobres", así que mandó que los conventos distaran al menos seis leguas unos de otros -alrededor de 34 kilómetros-. ${ }^{33}$

Aunque es verdad que la mayoría de los religiosos se concentraban en zonas templadas, también incursionaron en la Tierra Caliente, la costa y hacia el norte del río Lerma, donde, según Espinosa, predicaron a muchas bárbaras naciones, bautizando numerosos indios gentiles, como lo hicieron fray Francisco de Facuencia, ${ }^{34}$ fray Juan de San Miguel y fray Jacobo Daciano, entre otros. ${ }^{35}$ En estas regiones les fue más difícil la penetración que en aquellas que habían pertenecido al señorío tarasco, pues las hostilidades de los naturales estaban siempre latentes. Hacia el norte, los llamados “chichimecas" les dieron constantes problemas durante toda la segunda mitad del siglo xvi; y cuando se logró penetrar, por su lejanía con el centro de evangelización, las visitas eran intermitentes, lo que hizo que el proceso fuera más lento y complicado.

Respecto a los tipos de conventos, existían básicamente tres bien determinados: las guardianías, que eran conventos a cargo de un guardián, levantados en cabeceras territoriales de antecedente indígena o en poblados de cierta importancia; en

\footnotetext{
32 En su estancia en España, a mediados del siglo xvi, consiguió una cédula real, con fecha de 1555, para que no se continuara la construcción de este convento. Beaumont, Crónica de Michoacán, t. II, p. 306.

33 RicARD, La conquista espiritual, pp. 160-161.

34 Espinosa, Crónica de la provincia, p. 95.

35 Escobar, Americana Thebaida, pp. 60-61.
} 
ellos residían de cuatro a seis frailes -o más cuando los conventos albergaban estudios o noviciado-; desde ahí se organizaba un territorio denominado doctrina o convento-doctrina. Sus funciones eran la evangelización de la población autóctona, la vida conventual de la comunidad religiosa, la asistencia a la población y a la congregación conventual, entre otras. De las guardianías dependían las vicarías o asistencias, que ayudaban a las primeras $y$, consecuentemente, las visitas o misiones, que eran pequeños asentamientos con su capilla y casa, que no tenían la residencia permanente de un fraile, sino que eran visitadas esporádicamente por un religioso misionero para celebrar misas, adoctrinar y administrar los sacramentos. ${ }^{36}$

Los misioneros permanecían corto tiempo en los lugares que iban reconociendo, lo suficiente para bautizar a la gente, hablar por medio de los intérpretes con los principales, descansar y tomar algún alimento antes de continuar su labor. Una de las claves del éxito de los evangelizadores en la consolidación de sus doctrinas fue el apoyo de los propios indígenas que se encargaban de procurar que se llevaran a efecto las indicaciones de los frailes, tanto respecto a la construcción de edificios como a las obligaciones de la vida cristiana. Cuando el fraile se ausentaba dejaba en su lugar a indios fiscales, buenos cristianos, que celasen la asistencia a la doctrina y que velasen el mantener las buenas costumbres. ${ }^{37}$ Aun así, las ausencias de los religiosos podían ser prolongadas, por lo que muchas veces fueron interpretadas como abandono de los indios, y algunas fundaciones como Charo, Ucareo, Cuitzeo y Yuririapúndiro, que habían sido visitas franciscanas, fueran retomadas por los agustinos, mientras que Tlazazalca, Chilchota y Jacona pasaron al clero diocesano. ${ }^{38}$

36 Paso y Troncoso (recop.), Epistolario de la Nueva España, p. 166.

37 Espinosa, Crónica de la provincia, p. 170.

38 Chauvet, Los franciscanos en México, p. 54. 
En referencia a quiénes fabricaban los edificios religiosos, se sabe que, a diferencia de otras órdenes que solían traer de Europa alarifes, artesanos, carpinteros, canteros y pintores para que dirigieran determinadas obras en la Nueva España o para que enseñaran a los nativos los distintos oficios, los franciscanos se enorgullecían de levantar sus propios edificios con la única ayuda de los indios. La limitada experiencia y poca supervisión de los religiosos, combinado con el desconocimiento de los nativos de ciertos sistemas constructivos, herramientas y fundamentos de la arquitectura europea, no siempre tuvo buenos resultados. Por esta razón, no era raro que algunas edificaciones tuvieran deficiencias constructivas y que el rey solicitara enviar a dos o tres buenos oficiales para que anduvieran "por todas la tierra viendo obras y enmendando muchos defectos". 39

Con las disposiciones congregacionales se comenzó a organizar a los indios para que se encargaran de construir sus propias casas y luego trabajaban en la construcción de capillas, templos, conventos, hospitales, edificios de gobierno y cárceles, de acuerdo a sus recursos y capacidades, ${ }^{40}$ pero también de acuerdo a sus aspiraciones, es decir, una población numerosa no representaba necesariamente una construcción más amplia o vistosa, y en ocasiones pueblos pequeños competían para que su iglesia, capilla o convento fuera mejor o más grande que el del pueblo vecino. ${ }^{41}$ A pesar de los inconvenientes antes referidos, los conventos y capillas en este periodo estaban mejor construidos que en los primeros años de la conquista espiritual, pero no dejaban de tener una "traza humilde y moderada". ${ }^{42}$

Una vez que se conformó una cadena de conventos mejor construidos alrededor del lago de Pátzcuaro, los franciscanos comenzaron a fundar otros en varios pueblos de la sierra

39 Zavala, El servicio personal de los indios, p. 509.

40 Gerhard, "Congregaciones de indios", p. 366.

${ }^{41}$ Ricard, La conquista espiritual, p. 279.

${ }^{42}$ Cuevas, Historia de la Iglesia en México, t. II, p. 186. 
central de Michoacán y Jalisco, unas pocas visitas en la Tierra Caliente y se comenzó a incursionar hacia el norte del río Lerma. Hay que recordar que con el descubrimiento de las minas de Zacatecas, en septiembre de 1546, se comenzó a poblar el norte de la Nueva España y en varios de los asentamientos existentes se levantaron conventos. De esta manera, se fundaron conventos en Chamacuero -1565-, Querétaro-1567-y Celaya -1570-, mientras que los de Acámbaro y San Miguel el Grande, que eran visitas, se convirtieron en guardianías hacia 1543.

Datos proporcionados por Carrillo Cázares indican que para 1559 sólo se habían construido en la provincia michoacana los conventos de Acámbaro, Colima, Erongarícuaro, Peribán, Tancítaro, Tarecuato, Tarímbaro, Taximaroa, Tuxpan, Tzintzunzan, Uruapan, Jiquilpan, Zapotlán y Zinapécuaro ${ }^{43}$-no menciona conventos como los de Valladolid o Zacapu, que otros consideran anteriores a esa fecha-, mientras que en la parte de Jalisco existían unos 16 conventos. ${ }^{44}$ Las fechas exactas de la fundación de estos conventos y los que les siguieron son difíciles de precisar porque en la mayoría de los casos no existen los registros de dichos acontecimientos, ni siquiera en los archivos franciscanos, y las crónicas se contradicen o son difíciles de corroborar, por ejemplo, las que da el cronista Tello para la parte de Jalisco. ${ }^{45}$ Por su parte, Espinosa presenta una lista de los conventos fundados en Michoacán y Jalisco, pero no ofrece fechas para la mayoría. ${ }^{46}$

\footnotetext{
43 Carrillo, Michoacán en el otoño del siglo XVII, p. 80.

44 Tello, Crónica miscelánea.

45 Tello, Crónica miscelánea, p. 246.

46 1. Santa Ana de Tzintzuntzan, 2. San Buenaventura de Valladolid, 3. Santiago de Querétaro, 4. Concepción de Celaya, 5. San Francisco de Pátzcuaro, 6. San Felipe, 7. Zinapécuaro, 8. Asunción de María Santísima de Erongarícuaro, 9. San Jerónimo Purenchécuaro, 10. San José Taximaroa, 11. Acámbaro, 12. Santa Ana Zacapu, 13. Uruapan, 14. Peribán, 15. Tancítaro, 16. Tarecuato, 17. San Juan Bautista Zitácuaro, 18. San Francisco Jiquilpan, 19. Apaseo, 20. San Francisco Tarímbaro y 21. San Pedro Tolimán. En Jalisco: 1. San Francisco Guadalajara, 2. San Francisco Colima,
} 
Por otro lado, para los religiosos, la importancia de los conventos estaba más relacionada con su funcionamiento que con su tamaño o materiales de construcción. Si bien, para que un convento pudiera tener funciones importantes, como ser casa capitular, se requería que tuviera los espacios adecuados, en los inicios de la evangelización de ciertas áreas geográficas había conventos que tenían amplia jerarquía en varias leguas a su alrededor, a pesar de ser una construcción primitiva.

Al formarse la provincia franciscana de los Santos Apóstoles de San Pedro y San Pablo de Michoacán y Jalisco en 1565, independiente de la del Santo Evangelio, los hermanos menores de San Francisco se habían fortalecido y habían superado muchos de los obstáculos encontrados en los primeros años de la evangelización. A partir de este año, Tzintzuntzan cedía la cabeza de la provincia franciscana al convento de Buenaventura de Valladolid, que también iniciaba una nueva etapa en la historia de Michoacán, al obtener la silla episcopal, que por su muerte había dejado vacante el primer obispo de Michoacán, don Vasco de Quiroga. ${ }^{47}$

Entonces, la provincia de San Pedro y San Pablo estaba fundada en dos obispados: el de Michoacán y el de Jalisco -y a partir de 1584 en un arzobispado: el de México, al que pertenecía Querétaro-. Dicha provincia tenía, según Ciudad Real, 120

3. Purísima Concepción de Etzatlán, 4. N. Patriarca Seráfico de Ahuacatlán, 5. San Francisco Juchipila, 6. Asunción de Zapotlán, 7. San Juan Bautista Tuxpan, 8. Transfiguración de Autlán, 9. Santa María Magdalena de Zapotitlán, 10. San Francisco de Sayula, 11. San Francisco de Zacoalco, 12. San Sebastián Techalutla, 13. San Francisco Amacueca, 14. San Juan Evangelista Atoyac, 15. San Miguel Teoquitlán, 16. San Andrés Ajijic, 17. San Francisco Chapala, 18. Santos Apóstoles de San Pedro y San Pablo de Poncitlán, 19. Arcángel San Miguel Cocula, 20. San Antonio Tlajomulco, 21. San Francisco Teul, 22. Concepción Purísima de la Virgen María de Jala (Jala), 23. San Juan Bautista de Jalisco, 24. San Francisco Zanticpac, 25. San Francisco Guaynamota y 26. Sinaloa. Espinosa, Crónica de la provincia, pp. 240 y 246. 47 Espinosa, Crónica de la provincia, pp. 230 y 231. 
leguas de oriente a poniente y pocas -no dice cuántas- de norte a sur, ${ }^{48}$ abarcando el mismo territorio que tenía la custodia. El número de conventos que tenía la provincia de Michoacán al momento de su formación, en donde se administraban los sacramentos y enseñaban la doctrina, era de 22, con un total de 33 sacerdotes. ${ }^{49}$ Ciudad Real dice que para ese momento Jalisco se había quedado con 22 conventos y Michoacán con 23. En total sumaban 125 frailes, de los cuales 78 se encontraban en Michoacán y 57 en Jalisco, después que suprimió tres presidencias en Jalisco. ${ }^{50}$

\section{ETAPA 3. RECONSTRUCCIÓN, 1570-1650}

La tercera etapa, de "reconstrucción", la fijamos de 1570 a 1650. En este periodo se construyeron algunos conventos nuevos, mientras que la mayoría de los que ya existían se ampliaron o reconstruyeron con materiales menos perecederos. Prácticamente todos los conventos que adquirieron mayor jerarquía en la provincia se encontraban en ciudades o villas con importante población española, ubicados al norte del río Lerma; precisamente en estos centros de población, donde la economía se estaba fortaleciendo gracias a la producción minera, agrícola y ganadera, se destinaban mayores recursos para la fábrica material de los edificios de regulares y seculares.

Un informe que puede dar una idea de la situación constructiva de los conventos en el último cuarto del siglo xvi es el que se emitió después de la visita del comisario general de la orden, fray Alonso Ponce, a la provincia de Michoacán entre 1585 y 1587. Se puede notar que de los 48 conventos que se describen 11 estaban en proceso, otros 11 eran de cal y canto, siendo la mayoría

${ }^{48}$ Ciudad Real, Tratado curioso y docto, p. 64.

49 Morales, "Los franciscanos en la Nueva España”, p. 76.

50 Ciudad Real, Tratado curioso, vol. 2, p. 64. 
de adobe, madera y paja. Únicamente el de Tzintzuntzan es calificado como bueno, acabado y con retablo vistoso; también es el único que, según dicho informe, tenía gran vecindad de tarascos. Asimismo, se destaca el de Querétaro, que es descrito como amplio, donde hay mucha vecindad de otomíes; la iglesia de Tlajomulco es calificada como capaz; los conventos de Acámbaro, Tancítaro y Sayula son clasificados como medianos y 22 más como pequeños. A pesar de que el de Tzintzuntzan era de los más grandes y con mayor población de la provincia, para esos momentos tenía solamente 2 religiosos, al igual que 31 conventos más, en tanto que otros contaban con 1, 3, 4-Celaya, Uruapan y Tarecuato-, 5 -Querétaro-, 6 -Valladolid-, 7 -Acámbaro-, y hasta 16 -Guadalajara-. ${ }^{51}$ Las razones por las que varios conventos llegaban a albergar tal cantidad de religiosos tenían que ver con el número de visitas que atendían y las actividades que se desarrollaban en ellos, como estudios y noviciados.

Con las descripciones de Ponce se puede notar que en las últimas décadas del siglo xvi la mayoría de los conventos eran de materiales perecederos, pequeños o en proceso de construcción. Estas últimas se estaban levantando con muros de adobe o calicanto, es decir, se ponía mayor empeño en su fábrica. En el caso de Valladolid, se estaba haciendo uno fuerte, de calicanto, mismo que se concluyó hasta 1626, con su templo. De los 48 conventos descritos en el informe de Ponce -o 49 contando a San Andrés Tziróndaro, del que sólo se dice que se estaba haciendo-, 24 se situaban en Michoacán y 24 en Jalisco; eran atendidos por 130 religiosos en total, de los cuales 67 pertenecían a Michoacán y 63 a Jalisco.

Una crónica dice que para 1585 se contabilizaban 46 conventos y el número de religiosos ascendía a 214, incluyendo coristas,

51 Ciudad Real, Tratado curioso, vol. 2. 
legos y novicios. ${ }^{52}$ Unos años después, la cantidad de conventos había aumentado a 54 y en poco tiempo se había llegado a la cifra de $70,{ }^{53}$ incluyendo asistencias y vicarías, ${ }^{54}$ por lo que se reconocía a ésta como la provincia franciscana más numerosa en conventos y en religiosos regulares de todos los territorios sujetos a España, después de la del Santo Evangelio..$^{55}$

Para el último cuarto del siglo xvi, la mayoría eran construcciones de mala calidad, como lo afirmó fray Miguel López -en algún momento entre 1585 a 1588-:56

[...] los conventos de su orden, de la provincia de Michoacán, están cubiertos de paja y las paredes son de adobes, a cuya causa es en ellos con indecencia y peligro el SSmo. Sacramento, suplicándome atento a ello y su necesidad y que algunos de los dichos conventos están en fronteras de indios de guerra y a riesgo de quemarse como algunas veces ha sucedido con rayos que han caído en ellos, mandase se hiciesen de buen edificio [....$^{57}$

52 Espinosa, Crónica de la provincia, p. 243.

53 Mendieta, Historia eclesiástica, p. 377.

${ }^{54}$ En algunos documentos oficiales de la orden se habla de vicarías, presidencias o asistencias como la misma cosa. En otros están separados. La asistencia auxiliaba a un convento en específico, mientras que las vicarías o presidencias eran conventos de menor jerarquía que las guardianías pero que tenían una jurisdicción propia, similar a la que tenían las guardianías.

${ }^{55}$ Espinosa dice que para 1586 había 21 en Michoacán y 26 en Jalisco, mientras que Mendieta apunta que a finales del siglo xvi había 54 conventos franciscanos en Michoacán y Nueva Galicia. Espinosa, Crónica de la provincia, pp. 100, 335, 240 y 246. Mendieta, Historia eclesiástica, p. 377.

${ }^{56}$ El convento de Erongarícuaro, por ejemplo, se estaba construyendo, pues antes era "una casa de paja no decente para poder vivir", por lo que el virrey Gastón de Peralta ordenó en 1567 continuar la obra. AGN, T, vol. 2737, exp. 19, 5 fs. Que Juan del Hierro, alcalde mayor de Mechuacan informe sobre lo que piden los de Erongarícuaro, 1565. PAREdes et al., Michoacán en el siglo XVI, pp. 286-388. Hernández, “El convento de Nuestra Señora”, p. 75.

57 BNM, F, c. 52, 3404, fs. 10-12. Informe del venerable definitorio de la provincia de San Pedro y San Pablo de Michoacán, sobre el número de conventos cabeceras y religiosos que residen en ellos, Querétaro, 19 de junio de 1696. 
A finales del siglo xvi muchos se reconstruyeron con materiales más sólidos, pero con la austeridad que distinguía a la orden. $\mathrm{Al}$ respecto, el rey Felipe II había ordenado en 1594 lo siguiente:

Os mando proveáis que los conventos de la dicha orden de San Francisco de dicha provincia de Michoacán se hagan como convenga teniendo cuenta de que sean humildes y no haya en ellos superficialidad y que la costa se reparta en esta manera: que en los pueblos que exhibieren en mi corona se hagan de mi hacienda ayudando a la obra los indios de los tales pueblos y en los pueblos encomendados a personas particulares a mi costa y del encomendero y también ayuden los indios de los pueblos encomendados y tenéis de ellos el cuidado que conviene advirtiendo que en un pueblo ni en la comarca del no se haga más de un monasterio de la dicha orden que por esta mi cedula mando a los mis oficiales esa tierra que lo de mi hacienda se hubiere de pagar para el dicho edificio y conforme a lo sobredicho lo paguen luego y avisameis de lo que en ello se hiciere. Hecha en Madrid a siete de febrero de mil quinientos y noventa y cuatro. ${ }^{58}$

Teniendo esta disposición real, el virrey de la Nueva España, don Luis de Velasco, ordenó un año después que:

Se hagan los conventos de la orden de San Francisco de la provincia de Michoacán como convenga de manera que estén decentes y acomodados y de segura acotación para cuyo cumplimiento es acordado de mandar como por el presente mando a los alcaldes mayores corregidores en cuya jurisdicción hubiere comprender la dicha orden de San Francisco de la provincia de Michoacán que cada uno en su jurisdicción sea los conventos que hubiere en ella y me informe muy en particular del estado en que está el edificio de cada uno declarando el tamaño, altura y achura de la iglesia y casa de los

${ }_{58}$ BNM, Informe del venerable, fs. 13-15. 
religiosos y las oficinas que tienen y están con necesidad de reparos o de nuevo edificio y qué parte está necesitada de ello y qué tanto durará la obra y qué indios y de qué pueblos acudirán a ella y qué lengua hay en cada uno y a qué servicios van, y por cuyo mandado y si son de la Corona real o de encomenderos, y lo que costará el edificio, advirtiendo que han de ser las obras moderadas, como para religiosos de dicha orden, y de todo me envió razón y relación con su parecer jurado luego que este mandamiento o su traslado autorizado les fuere mostrado fecho en México a ocho días del mes de abril de mil quinientos y noventa y cinco D. Luis de Velasco por mandato del virrey. Martin López de Gama. ${ }^{59}$

Con estos documentos se refuerza la idea de que muchos de los edificios conventuales se reedificaron después de 1595 y durante la primera mitad del siglo XvII, coincidiendo con la última etapa de congregaciones. Los conventos en los que se puso más empeño en el siglo XVII fueron los de Valladolid, terminado en 1626; Querétaro, acabado cerca de 1640, y el de Celaya, reconstruido entre 1618 y $1637 .{ }^{6}$ En este periodo fue cuando se erigieron los espacios que albergaron el Colegio de la Purísima Concepción de Celaya. En el caso del de Tzintzuntzan, ya habían comenzado a reconstruirse antes de que el rey Felipe II lo solicitara, terminándose la mayor parte del convento antes de 1586, mientras que el templo fue concluido en $1601 .^{61}$

La labor evangélica y la actividad constructiva de los franciscanos de la provincia de Michoacán cambió de un sistema de penetración y fundación básica hacia distintas direcciones, a una actividad administrativa de las doctrinas y a una estrategia de consolidación en los lugares donde ya se encontraban establecidos, teniendo una especial atención a las doctrinas de

59 BNM, Informe del venerable, fs. 16-17v.

60 EsCANDÓn, "La provincia franciscana”, p. 21.

${ }^{61}$ Martínez, "Las cofradías novohispanas", p. 52. 
la llamada Gran Chichimeca, donde se encontraban centros mineros, estancias de ganado y pueblos de frontera. ${ }^{62}$ Hay que recordar que en 1570 el virrey organizó una campaña militar contra los huachichiles, indios chichimecas que amenazaban los centros mineros en auge, para lo cual fundó en Zacatecas los presidios de Ojuelos y Portezuelos, y en Guanajuato el de San Felipe. Además, se fundó la villa de Celaya en 1571, y en 1576, la villa de León.

Ya desde el siglo xvi los frailes de las provincias de Michoacán y Jalisco habían hecho incursiones a territorios del Bajío, norte, noreste y noroeste de la Nueva España, fundando misiones en los actuales estados de Nayarit, Sinaloa, San Luis Potosí, Zacatecas, Durango, Nuevo León, Tamaulipas, Nuevo México, Texas y otros lugares, pero es durante el siglo xvir que algunas de ellas se empezaron a consolidar. Por ejemplo, las misiones de Nuevo México conformaron la custodia de San Pablo en 1616. Hacia Texas también se enviaron varios grupos de religiosos que se habían especializado en el Colegio Apostólico de Propaganda Fide, quienes fundaron el convento de la Santa Cruz de Querétaro hacia 1683 . De este colegio surgieron también religiosos que trabajaron en las misiones de Río Verde. ${ }^{63}$

La labor misionera en Río Verde, actual estado de San Luis Potosí, no había sido fácil. Los primeros religiosos habían intentado pacificar la región y evangelizar a sus habitantes fundando algunas misiones, hasta que llegaron a erigir la custodia de Santa Catarina Mártir en 1621, a cargo del comisario general de los franciscanos de la Nueva España. No obstante, después de que algunos misioneros y colonos fueron sacrificados y la mayoría de las misiones incendiadas, se determinó en el capítulo general de Toledo, de 1641, que dicha custodia quedara nuevamente

62 Escandón, "La provincia franciscana”, p. 4.

${ }^{63}$ Font, "Desarrollo y consolidación”, pp. 221-284. Cruz et al., Indios y franciscanos. 
sujeta a la provincia de San Pedro y San Pablo. Caso similar fue el que sucedió con las primeras misiones de la Sierra Gorda queretana, que tuvieron breve existencia ante la hostilidad que mostraron los indígenas de la región. ${ }^{64}$

Los dos entes que organizaban el territorio franciscano denominado provincia de San Pedro y San Pablo de Michoacán y Jalisco tenían su cabeza principal en Valladolid; ambas compartían estrategias, recursos humanos, pero a la vez tenían cierta independencia, pues a partir del convento de Valladolid se hacían algunas incursiones y se administraban un número determinado de conventos, mientras que desde el convento de Guadalajara se hacía lo propio. Como se habían multiplicado los conventos y muchos de ellos se encontraban consolidados, en el Capítulo General celebrado en 1606 en la ciudad de Toledo, se pidió la separación definitiva de los dos territorios. Después de haber hecho la división de religiosos y conventos se eligieron dos provinciales y ocho definidores, votando los de cada provincia por su provincial y definidores.

La provincia de Michoacán quedó con 39 conventos, de los cuales 33 eran guardianías y 6 presidencias, "con iglesias muy decentes, y lo necesario para el divino culto”, mismo número que mantenían cincuenta años después. ${ }^{65}$ En 1622 los franciscanos de la provincia de Michoacán administraba más de 150 localidades, incluyendo ciudades, villas, pueblos, haciendas, estancias y labores. ${ }^{66}$

La multiplicación de los conventos requería de más ministros que los condujeran, y el número de religiosos que eran formados en los noviciados de la provincia de Michoacán no eran

64 Rangel, "Pames, franciscanos y estancieros", p. 229.

65 AHCM, D, G, RF, S. XVII, c. 17, leg. 57, carp. 27, f. 42. Tabla capitular de la provincia de San Pedro y San Pablo de Michoacán, 1676.

66 CEHM, CCXX-1, 15 fs. Copia y minuta de los pueblos cabeceras y visitas y vecinos tributarios y conventos que hay en esta provincia de Mechoacán, año de 1622, Erongarícuaro, 15 de agosto de 1622. 
suficientes, por lo que se seguían dando autorizaciones para que pasaran a este territorio grupos formados por europeos, en su mayoría españoles peninsulares. Como los criollos superaban por mucho el número de los peninsulares, se buscaba equilibrar las parcialidades y evitar más pugnas de las que ya se habían generado por ocupar los cargos principales en la orden. ${ }^{67}$

Si durante casi todo el siglo xvi los franciscanos se habían ocupado de levantar edificios modestos en la provincia michoacana, para finales del mismo siglo y parte de la siguiente centuria los nuevos templos y conventos de esta orden fueron, como se dijo antes, mejor construidos y más amplios. Los frailes seguían administrando y adoctrinando a los indios, pero también a españoles y castas. De hecho, los edificios más destacados fueron los que se emplazaban en ciudades habitadas por numerosas familias españolas, como la ciudad de Valladolid y las villas de Querétaro, Celaya y San Miguel el Grande, donde, por cierto, los españoles de la provincia y los frailes competían, tenían pugnas y roces con los cabildos de las ciudades, los alcaldes mayores y la jerarquía diocesana. ${ }^{68}$ En estos asentamientos, el aumento de la población criolla significó una mayor canalización de recursos económicos y humanos para el establecimiento de colegios, conventos de monjas y fundación de cofradías, pero también coadyuvó en el fortalecimiento económico de los conventos mendicantes, incluyendo los franciscanos quienes, a pesar de su voto de pobreza, enriquecían sus templos con obras de arte y ornamentos de plata para el culto, mediante las aportaciones de las mismas cofradías, las capellanías, dotaciones, obras pías y limosnas del resto de la población, al menos hasta que la secularización de los curatos y doctrinas tuvo efecto.

67 Rubial, “Las órdenes mendicantes”, p. 224; Becerril y Cerda, Catálogo de documentos, p. 122; EsCANDÓN, "La provincia franciscana”, p. 80.

68 Escandón, “La provincia franciscana”, pp. 6 y 177. 
Es importante resaltar que, a pesar de que el convento de Valladolid fue desde 1565 la sede oficial de la provincia, el convento de San Francisco de Querétaro fue durante casi todo el siglo XVII el lugar en donde tenían lugar las reuniones capitulares y donde residían la mayoría de los provinciales. Este convento se encontraba en una ciudad que cobraba cada vez más importancia y cuya ubicación geográfica era estratégica para el funcionamiento de la orden, por encontrarse en el camino entre la ciudad de México y las minas de Zacatecas, en la frontera noreste de los conventos de la sierra de Michoacán, al este de los conventos del Bajío guanajuatense y al sur de las misiones de Río Verde. Pero quizá la verdadera razón de que las reuniones no se realizaran en Valladolid era evitar la intromisión de la élite diocesana en los asuntos de la orden regular.

ETAPA 4. AMPLIACIÓN Y MEJORAMIENTO, 1650-1750

A partir de la segunda mitad del siglo xvir y la primera del xviII, algunos de los conventos de la provincia se reconstruyeron, ampliaron y mejoraron; muchos templos de los conjuntos conventuales también se agrandaron, sus muros y artesones -o bóvedas interiores- se decoraron con pintura sacra y se embellecieron con retablos, imágenes y lienzos costosos, gracias a donaciones de particulares y a la ayuda económica de las cofradías; a esta etapa la llamamos de "ampliación y mejoramiento". En este lapso de tiempo se fundaron muy pocos conventos, como el de Tlalpujahua en 1703 y el de Santiago Apóstol de Silao en 1739.

En la segunda mitad del siglo xvir la Nueva España se había consolidado y adquirido cierta autonomía política y económica respecto a su metrópoli, con base en el comercio, la ganadería y la producción agrícola. En este periodo, la mayoría de las instituciones eclesiásticas, incluyendo las órdenes religiosas y las cofradías de los pueblos, también se consolidaron. La cultura floreció en todos los ámbitos, sin exceptuar la arquitectura de 
los franciscanos, ya fueran capillas, templos o conventos, se embellecieron con pintura y escultura barrocas. Desde luego que la primera mitad del siglo xviII fue una etapa de altibajos para la provincia. Por un lado, las medidas impuestas por los Borbones comenzaron a tener mayor control sobre las finanzas de las diferentes doctrinas a la vez que limitaban la influencia que los religiosos habían tenido en la toma de decisiones, principalmente en los pueblos de indios. Por otro lado, se habían fundado numerosas cofradías de indios y españoles por toda la provincia, con bienes que les permitían sostenerse a sí mismas, realizar las fiestas religiosas de cada año y pagar misas y arreglos de los templos, capillas, conventos. A principios de este siglo, el número de conventos había aumentado poco en relación con los que había un siglo antes, pero la mayoría de ellos, al igual que los templos, se habían renovado y ampliado de nuevo, o lo harían en las siguientes décadas, principalmente aquellos que se encontraban en ciudades y villas de españoles, o de predominancia criolla, que se sostenían de la extracción minera, las estancias ganaderas y las haciendas agrícolas.

Un ejemplo claro fue el templo de Celaya, que se demolió en 1682 para dar paso a un nuevo edificio que quedó concluido en 1715; sólo le faltaba la torre, que se terminó diez años después. ${ }^{69}$ Para ese entonces fue uno de los conventos más imponentes de la provincia. En sus instalaciones se había fundado en 1624 el Colegio de la Purísima Concepción y hacia 1725 comenzaba a funcionar la Universidad Real y Pontificia. ${ }^{70}$ El convento de San Francisco de Querétaro, por su parte, se reconstruyó en 1664, junto con la torre, enfermería y capilla, aunque el claustro se concluyó hasta 1698; en el siglo siguiente, los interiores del templo fueron decorados con ricos y costosos

${ }^{69}$ Los retablos, fachada y cúpula que se ven en la actualidad fueron obra del arquitecto Tresguerras en el siglo xIx.

70 López, La Universidad Real, p. 21. 
retablos y lienzos. Un ejemplo más es el templo de San Francisco de Acámbaro, que se rehízo entre 1734 y 1743, y el convento de Santa María de Gracia, en el mismo lugar, que fue edificado entre 1744 y $1749 . .^{71} \mathrm{El}$ templo antiguo de Guatzindeo -actual Salvatierra- quedó abandonado y se erigió uno nuevo dedicado a San Buenaventura en 1743. Al templo de Chamacuero -actual Comonfort-se le colocaron retablos churriguerescos entre 1765 y 1789 y sus muros fueron decorados con óleos que se atribuyen a Miguel Cabrera. El convento y templo de Tzintzuntzan tuvo poca actividad constructiva en este periodo, pero sí se edificaron varias capillas en la ciudad alrededor de 1750 , gracias a las cofradías y obras pías. ${ }^{72}$ En resumen, se pudo detectar que en los principales conventos, especialmente los que se encontraban al norte de la provincia, los feligreses, por medio de las cofradías o de manera particular como obras piadosas, mandaron construir retablos barrocos de madera y pintar cuadros de temas religiosos para adornar los templos y capillas. Además, muchas de las capillas de visita ubicadas en toda la provincia fueron construidas o reconstruidas en el siglo xvir, y sus campanarios y remates del frontispicio corresponden a finales de este siglo y al posterior, como dan testimonio sus vestigios y algunas inscripciones en sus muros y piezas de cantería.

En este periodo también se dio inicio a una importante actividad misional al norte de la Nueva España. Con la finalidad de impulsar nuevamente la actividad pastoral, sobre todo en los pueblos chichimecas y otomíes de los actuales estados de Tamaulipas y San Luis Potosí, el franciscano Antonio Linaz y 24 frailes más fundaron el primer Colegio de Propaganda Fide de toda América, para lo cual les fue asignado el convento de la Santa Cruz de los Milagros de Querétaro, perteneciente a la provincia de Michoacán. Este centro de preparación para

\footnotetext{
71 Anónimo, Conjunto Arquitectónico, pp. 7-8.

72 Martínez, "Las cofradías novohispanas, pp. 11-57.
} 
los misioneros fue el centro de irradiación misionera hacia los pueblos de la frontera norte de la Nueva España desde 1683 hasta 1860, año en que se dio la exclaustración de los frailes; sin embargo, su trabajo tuvo trascendencia continental, porque de aquí surgieron los colegios de Cristo Crucificado en Guatemala, Guadalupe en Zacatecas, San Antonio en Texas, San Francisco en Pachuca, San Fernando en México y Zapopan en Jalisco. ${ }^{73}$

Hacia el territorio conocido como Río Verde los franciscanos enviaron algunos misioneros desde 1612, logrando erigir la custodia de Santa Catarina Mártir en 1621, independiente de la provincia de Michoacán, pero en el Capítulo General de Toledo de 1641 se determinó que ésta quedara nuevamente sujeta a la provincia de San Pedro y San Pablo, a cargo del convento de Valladolid. Para entonces ya funcionaban las misiones de San Antonio de las Lagunillas, Nuestra Señora de la Presentación de Pinihuán, San Felipe de Jesús de los Gamotes, Nuestra Señora de la Concepción del Valle del Maíz. También se administraban la de San Antonio de Tula, San Juan Bautista de Jaumave, Nuestra Señora de los Ángeles de Monte Alberne, Santa Catarina de las Montañas y San Cristóbal de Río Blanco, en el actual Nuevo León. Después se agregaron la de Santa María Teotlán, San Pedro Mártir de las Alpujarras y San Juan Tetla, en la Sierra Gorda queretana, aunque las últimas seis tuvieron breve existencia ante la hostilidad de los indígenas de la región. ${ }^{74}$ Luego, en 1671, parte de la custodia de San Salvador de Tampico se agregó a la de Río Verde, aumentando el número de misiones dependientes de la provincia Michoacana. ${ }^{75}$

A finales del siglo XviI, el provincial fray Pablo Sarmiento informó que el convento sede de la custodia de Santa Catarina tenía claustro y celdas suficientes para 4 religiosos; que los

73 GonzÁLez, Estructura, organización y vida.

74 Rangel, "Pames, franciscanos”, p. 229.

75 Chauvet, Los franciscanos en México, p. 230. 
indios eran de nación otomí y que había otros pueblos en la misma custodia de nación chichimeca y pames. Por todos, dice, son 60 familias, 6 estancias de españoles, mestizos y mulatos, de las cuales da detalle. ${ }^{76}$ En cuanto a la provincia de San Pedro y San Pablo, un informe de 1696 emitido por el mismo padre Sarmiento indicaba que las doctrinas de dicho territorio eran 29, las vicarías 13, una custodia con 5 misiones y una hospedería, la de Acapulco. ${ }^{77}$ De acuerdo a una relación de este tiempo, la provincia de Michoacán tenía 144 religiosos, ${ }^{78}$ aunque otro informe indicaba que eran 228, que atendían 42 casas y 2 misiones. ${ }^{79}$ Es posible que la diferencia se deba a que en la segunda se incluían coristas y legos, como se hizo unas décadas después, en 1733, cuando se informó que los religiosos sumaban 337, según una nómina, de los cuales 39 eran españoles, 180 criollos, 83 coristas y 35 legos. ${ }^{80}$ En 1751 se contaban 221 religiosos, ${ }^{81}$ y en 1762 se registraron 298 frailes, 53 españoles y 245 criollos. Entre los españoles se contabilizaban 48 sacerdotes, corista y 4 legos; de los criollos, 199 eran sacerdotes, 19 coristas y 27 legos. ${ }^{82}$ Tres años después se tenían 41 españoles, 208 criollos, 26 legos y 13 novicios, que sumaban un total de 288 religiosos (ver tabla 1 ). ${ }^{83}$

76 AGN, $H$, vol. 30, exp. 3, Testimonio y razón del estado en que hoy se halla la custodia del Río Verde sujeta a esta Sta. Provincia de los Apóstoles San Pedro y San Pablo de Michoacán, por el padre fray Pablo Sarmiento Ministro Provincial, 1695.

77 BNM, Informe del venerable, fs. 10-17 v.

78 BNAH, F, vol. 134 (rollo 44), fs. 101-102, Lista de los religiosos de la Provincia de Michoacán, durante el provincialato de fray Pablo Sarmiento, 1694-1696.

${ }^{79} \mathrm{BNM}$, Informe del venerable, fs. $10-17 \mathrm{v}$.

80 BNAH, F, vol. 134 (rollo 44), fs. 131-138, Nómina de los religiosos de la Provincia de Michoacán, 1733-1765.

${ }^{81}$ BNM, F, c. 51, exp. 1091, fs. 7-14, Razón de los conventos de esta provincia de San Pedro y San Pablo de Michoacán, jurisdicción, idiomas, familias y demás circunstancias, 1751.

82 BNAH, Nómina de los religiosos, fs. 84-89.

83 BNAH, Nómina de los religiosos, fs. 93-100. 


\section{Tabla 1}

NÚMERO DE RELIGIOSOS DE LA PROVINCIA FRANCISCANA DE MICHOACÁN (1696-1765)

\begin{tabular}{cccccc}
\hline $\begin{array}{c}\text { Columna 1 } \\
\text { Año }\end{array}$ & $\begin{array}{c}\text { Columna 2 } \\
\text { Españoles }\end{array}$ & $\begin{array}{c}\text { Columna 3 } \\
\text { Criollos }\end{array}$ & $\begin{array}{c}\text { Columna } 4 \\
\text { Coristas }\end{array}$ & $\begin{array}{c}\text { Columna } 5 \\
\text { Legos }\end{array}$ & $\begin{array}{c}\text { Columna 6 } \\
\text { Total }\end{array}$ \\
\hline 1696 & $\ldots$ & $\ldots$ & $\ldots$ & $\ldots$ & 144 \\
1698 & $\ldots$ & $\ldots$ & $\ldots$ & $\ldots$ & 228 \\
1733 & 39 & 180 & 83 & 35 & 337 \\
1751 & $\ldots$ & $\ldots$ & $\ldots$ & $\ldots$ & 221 \\
1762 & 48 & 245 & 1 & 4 & 298 \\
1765 & 41 & 208 & 13 & 26 & 288 \\
\hline
\end{tabular}

FUENTE: elaboración propia con base en documentos arriba citados.

Durante casi todo el periodo virreinal, pero con más claridad en el siglo xviII, el número de conventos considerados guardianías, asistencias y vicarías había variado constantemente, porque unos cambiaban su jerarquía - de guardianía se degradaba a vicaría, o viceversa-. Se tiene información respecto a que en 1736 los conventos con la categoría de guardianías eran 17, más 19 asistencias, 19 visitas y 11 misiones, es decir, que la provincia franciscana tenía al menos 66 conventos a su cargo. Las guardianías eran Querétaro, Celaya, Valladolid, Tzintzuntzan, Pátzcuaro, Acámbaro, Taximaroa, Uruapan, Peribán, Zitácuaro, Jiquilpan, Apaseo, León, Salvatierra, Chamacuero, San Felipe y San Antonio del Valle de San Miguel. Las asistencias eran Contepec y Jerécuaro -de Acámbaro-, San Pedro de la Cañada, San Sebastián, Espíritu Santo, Huimilpan y Señora del Pueblito -de Querétaro-, San Juan Bautista de la Vega, Neutla, San Miguel, Comontuoso, Amoles y San Bartolomé del Rincón -de Celaya-, Cocupao -de Tzintzuntzan-, Chapatuato y San Mateo -de Zitácuaro-, San Cristóbal y Mazamitla -de Jiquilpan-, y San Bartolomé -de Apaseo-. Las vicarías eran Tarecuato, Zinapécuaro, Erongarícuaro, Zacapu, Tancítaro, Tarímbaro, Tolimán, Zichú, Charapan, Tuxpan, Amatlán, Apatzingán, Pichátaro, 
Patamban, Tlalpujahua, Acapulco, Ziróndaro, Purenchécuaro y el hospicio de Zamora. Un documento diferente, probablemente de fecha cercana al anterior, tiene los mismos datos, pero agrega como vicarías a San Ángel, los Santos Apóstoles de San Pedro y San Pablo de Pecuaro y Jarácuaro. Además menciona como misiones de la custodia de Santa Catarina a Pinihuán, Lagunillas, Camotes, Alaquines, Valle del Maíz, Tula, Jaumave, Monte Alberne, Santa María, Tetla y San Rafael. ${ }^{84}$

Un censo de 1751 presentaba información de 14 doctrinas de la provincia y una misión, por medio de la cuales se administraban alrededor de 78 pueblos, la mayoría de indios; 27 barrios que se encontraban en las ciudades o villas y más de 200 asentamientos menores, que incluían haciendas, ranchos y estancias. Las personas que administraban los franciscanos de la provincia michoacana sumaban 210178 repartidas en 42367 familias, de las cuales la mitad eran españolas y castas, la otra mitad indios, administrados en lengua tarasca, mexicana, otomí, mazahua y pame. ${ }^{85}$ Las doctrinas que tenían mayor número de personas a su cargo eran Celaya, León, Acámbaro y Querétaro.

ETAPA 5. SECULARIZACIÓN Y NUEVAS MISIONES, 1750-1790

Las medidas llevadas a cabo para la secularización de las doctrinas de las órdenes regulares, desde mediados del siglo XviII hasta la década de 1780, afectó sensiblemente el funcionamiento de las provincia agustina de San Nicolás Tolentino y la franciscana de San Pedro y San Pablo de Michoacán, más que al resto de

${ }^{84}$ BNAH, $F$, vol. 98. Tabla capitular de 1736. BNAH, $F$, vol. 98, Razón específica de los conventos de que se compone la provincia de los Santos Apóstoles San Pedro y San Pablo de Michoacán, sus guardianías, asistencias, vicarías y misiones, s. a., f. 238.

${ }^{85}$ BNM, Razón de los conventos. 
las provincias de la Nueva España. ${ }^{86}$ En este periodo se pasaron al clero diocesano 18 casas, de las 41 que tenía, incluyendo las visitas y misiones. ${ }^{87}$ Después de que se habían recogido la mayoría de los conventos y se habían restituido los que estaban fundados con licencia real o tenían al menos ocho frailes residentes antes de la secularización, el conteo de los religiosos sacerdotes, coristas y legos era de $274,20 \%$ menos que los que se contaban en 1733, de los cuales a muchos se les había mandado recluirse en alguno de los conventos de recolección. ${ }^{88}$

La imposición de un incisivo programa de secularización, impulsado por las autoridades reales y el clero diocesano desde mediados del siglo xviII, cambiaría el rumbo de la administración religiosa de manera determinante en la Nueva España. Mediante dos cédulas emitidas en 1749 y 1753, respectivamente, se ordenó que todas las doctrinas administradas por las órdenes mendicantes de ultramar fuesen entregadas para ser administradas por el clero secular. ${ }^{89}$ La justificación que externaban las autoridades para tomar estas medidas era que la mayoría de conventos en la Nueva España habían sido edificados sin la autorización legal correspondiente. Asimismo, consideraban que a pesar de que había un número excesivo de frailes, en la mayoría de los conventos sólo había uno o dos frailes residentes, además de que los mendicantes habían relajado su disciplina, inmiscuyéndose en asuntos que no les correspondían, y que algunos de los

\footnotetext{
${ }^{86}$ Cuando ya se habían secularizado tres conventos, 9 vicarías y 6 asistencias, los religiosos que quedaban eran 280 y 12 novicios. Los conventos con categoría de guardianía que quedaban eran 15, más 8 vicarías y 12 visitas. BNAH, $F$, vol. 134 (rollo 44), fs. 90-91. Lista de los conventos, vicarías y misiones que han quedado a la provincia de Michoacán, ca. 1763-1764.

87 Chauvet, Los franciscanos en México, pp. 147-148.

${ }^{8}$ BCUNAM, FA, E, CF, "Copia del estado de la provincia de Michoacán. Religión de N. P. S. Francisco”, Valladolid, 1771, Copia de los estados de los conventos de Santo Domingo de México y la Puebla, fs. 56-66.

${ }^{89}$ Brading, Una iglesia asediada, p. 77.
} 
conventos se estaban convirtiendo en establos, talleres textiles o refugios para pobres..$^{90}$

En realidad, lo que más molestaba a los Borbones, como lo había hecho con los monarcas predecesores, era que las órdenes religiosas tenían gran influencia en la vida de la sociedad novohispana y que las parroquias controladas por los frailes no contribuían a las cajas reales. Al respecto, el Conde de Revillagigedo, virrey de la Nueva España, exteriorizaba que las órdenes religiosas eran ya tan prósperas que absorbían la mayor parte de las riquezas de la corona, debilitando así su comercio con la Península. Fue así que, en una labor conjunta del virrey Juan Francisco de Güemes y Horcasitas y el arzobispo Manuel Rubio y Salinas, se ejecutó el retiro sistemático de las doctrinas entre 1749 y 1755 . Como era de esperarse, estas acciones desataron numerosas protestas por parte de los frailes y las repúblicas de indios, así como algunos grupos de españoles y criollos que veían en la secularización una amenaza para la supervivencia de sus cofradías y bienes. ${ }^{91}$

Mientras que el virrey de Güemes había ignorado la mayoría de las protestas e insistía en aplicar la transferencia de parroquias con agilidad, su sucesor, Agustín de Ahumada y Villalón, emitió un decreto en 1757 que facilitó el proceso. En él se determinó que se debía dejar a los frailes en el lugar en que habían sido canónicamente nombrados párrocos y que sus parroquias sólo serían secularizadas tras la muerte o renuncia del ministro que las ocupara, de modo que el proceso sería más gradual y más lento el traslado de los frailes de los pueblos a los conventos urbanos. Asimismo, determinó que todos los conventos que albergaban regularmente de ocho frailes en adelante se mantendrían abiertos y, si ya habían sido expropiados, se les devolverían. Agregaba que en cada provincia las órdenes religiosas

90 Brading, Una iglesia asediada, p. 78.

91 BRAding, Una iglesia asediada, p. 81. 
tenían derecho a conservar una o dos parroquias de las más prósperas, para que ahí pudieran residir los frailes y se educara a los religiosos que irían a las misiones del norte. Por último, les concedía conservar los conventos que se hubieran fundado con las solemnidades debidas y ratificaba que se respetarían aquellos donde vivieran ocho o más religiosos de continua habitación. ${ }^{92}$

En tanto que una gran parte de los conventos del centro de México habían perdido presencia, en la diócesis de Michoacán las antiguas misiones de frontera se habían convertido en prósperas ciudades rodeadas por ricas posesiones agrícolas. Esta prosperidad se había reflejado claramente en la materialidad de los edificios religiosos de la región, con ampliaciones erigidas de calicanto, altares ricamente decorados y muros embellecidos con lienzos de artistas de renombre.

Para mediados del siglo XVIII, los franciscanos mantenían en la provincia de San Pedro y San Pablo los tres grandes conventos de Querétaro, Valladolid y Celaya, así como 36 doctrinas. El número máximo de religiosos llegó a ser de 326 en 1755, de los cuales casi la mitad vivían dispersos en grupos de dos a cuatro. Los conventos de Querétaro y Valladolid tenían noviciados y enfermería, mientras que Celaya mantenía un colegio donde los estudiantes que concluían sus estudios obtenían un grado por la Universidad de México. ${ }^{93}$

Los intentos por parte de los franciscanos de la provincia de Michoacán no tuvieron el éxito que se esperaba, pero al menos los regulares lograron conservar algunas doctrinas, conventos y colegios. En 1785 se les concedió quedarse con el templo y cofradía de la Purísima Concepción de Celaya, que tenía uno de los mayores ingresos en toda la provincia. ${ }^{94}$ También consiguieron

92 AGN, RCO, vol. 7, exp. 77-78, Real Cédula modificante de 23 de junio de 1757.

93 BRAding, Una iglesia asediada, pp. 87 y 93.

94 Fray Domingo de Ocaranza consiguió la restitución de estas parroquias que habían sido secularizadas o que se pretendía secularizar argumentando que 
que se restituyera el curato de Acámbaro, con sus respectivas asistencias de Jerécuaro, Contepec y Coroneo, al igual que el templo de San Juan Zitácuaro. También se les permitió conservar la parroquia de San Juan de la Vega y las misiones de Río Verde, el Colegio de Santa Cruz de Querétaro y los conventos de Valladolid, Pátzcuaro, San Miguel y San Felipe, pero sin sus beneficios, sino como casas de recolección. ${ }^{95}$ Las fundaciones del siglo xviı, como Irapuato, el Pueblito, el hospicio de Zamora y el nuevo convento de Tlalpujahua no fueron afectadas por tener permiso real.

Los franciscanos lamentaron la pérdida de sus doctrinas, pero finalmente se resignaron a dejarlas atrás y se dedicaron a administrar los conventos que les quedaron, junto con las misiones en Nuevo México y Texas, por medio del Colegio Apostólico de Propaganda Fide de Santa Cruz de Querétaro. ${ }^{96}$ Un informe escrito entre 1772 y 1777 indica que por ese tiempo el número de religiosos era de 244 y les quedaban 12 conventos, 10 vicarías y 12 misiones. ${ }^{97}$ Lo que muestran las cifras es una disminución continua de religiosos de hasta 35\% en 40 años a causa de las medidas secularizadoras y a que se frenó la formación de nuevos ministros. Los que no se regresaron a España se recogieron en los conventos para llevar una vida de

los conventos tenían al menos 8 religiosos y que la cofradía había sido erigida mediante bula papal. BNM, 47: 1057.19, f. 89-89v. Carta de fray Domingo de Ocaranza al comisario general de Indias, fray Plácido de Pinedo, Querétaro, 20 de mayo 1767.

${ }^{95}$ Las casas de recolección eran aquellos conventos en los cuales los religiosos vivían la regla y constituciones de manera más rigurosa en cuanto a los votos de pobreza, clausura, oración y penitencia para "acentuar la devoción de los seglares y conservar la pureza de la orden". Escandón, "La provincia franciscana", pp. 134 y 140.

${ }^{96}$ Espinosa, Crónica de la provincia, p. 427.

97 BNAH, Nómina de los religiosos, fs. 76-78. Dice Chauvet que en 1785 le quedaban sólo 23 casas a la provincia y que se habían entregado 18 al clero secular. Chauvet, Los franciscanos en México, pp. 145-148. 
claustro o se especializaron en el Colegio de Propaganda Fide de Querétaro para ejercer su ministerio en las misiones del norte de Nuevo México.

Un censo de 1751 presentaba información de 14 doctrinas de la provincia y una misión, mediante las cuales se administraban alrededor de 78 pueblos, la mayoría de indios; 27 barrios que se encontraban en las ciudades o villas, así como más de 200 asentamientos menores, que incluían haciendas, ranchos y estancias. Las personas que administraban los franciscanos de la provincia michoacana sumaban 210178, repartidas en 42367 familias, de las cuales la mitad eran españolas y castas, la otra mitad indios, administrados en lengua tarasca, mexicana, otomí, mazahua y pame. ${ }^{98}$ Las doctrinas que tenían mayor número de personas a su cargo eran Celaya, León, Acámbaro y Querétaro.

Mientras se llevaba a cabo la secularización de muchos de los conventos de la provincia michoacana y sus doctrinas, los franciscanos fundaron cinco misiones en la Sierra Gorda de Querétaro, entre 1750 y 1762. Éstas fueron construidas por los pames que habitaban la región, bajo la dirección de varios frailes, entre los que destaca fray Junípero Serra, quien también fundó misiones en la Sierra Gorda de Querétaro y en California. Por esos mismos años se fundaron en la custodia de Río Verde las misiones de la Divina Pastora, Piedra Negras, Dulce Nombre de Jesús y San José del Valle, en la frontera con la Gran Chichimeca, con el objetivo de pacificar a los grupos nómadas que hostilizaban la demarcación. ${ }^{99}$

Para 1771 los ingresos de los conventos que aún pertenecían a los franciscanos llegaban a casi 200000 pesos, por concepto de misas, entierros, limosnas, obras pías y demás aportaciones de cofradías y particulares, concentrado en los conventos de Querétaro, Celaya, Valladolid, San Miguel, Salvatierra y

\footnotetext{
98 BNM, Razón de los conventos.

99 Rangel, "Pames, franciscanos", pp. 246-250.
} 
Pátzcuaro. Del resto sólo se dice que los religiosos se mantenían de las obvenciones. ${ }^{100}$

Los conventos que siguieron funcionando después de la secularización llegaron hasta mediados del siglo XIx, cuando, a partir de las leyes de nacionalización de bienes eclesiásticos, el gobierno federal recogió los edificios religiosos y buena parte de sus predios fueron vendidos al mejor postor. Muchos de los conventos se convirtieron en cuarteles militares, se utilizaron para oficinas o almacenes, mientras que otros quedaron abandonados y se vinieron abajo por falta de mantenimiento. No faltaron los que se quemaron, como el de Zamora, que se había fundado en 1791, el cual sucumbió en un incendio ocurrido en 1863, y la mayor parte del predio que había sido parte del conjunto conventual se dividió y fue vendido a particulares. ${ }^{101}$

\section{CONCLUSIONES}

La presencia de los franciscanos en la Nueva España ha sido motivo de interés para numerosos investigadores debido a la importancia que tuvieron en el devenir de los pueblos por ellos administrados. Sin embargo, siguen quedando lagunas y confusión sobre diversos aspectos relacionados con su actuar, por ejemplo, respecto al uso y temporalidad de los edificios erigidos en sus doctrinas y misiones, que fueron indispensables para que su labor pudiera llevase a cabo de manera eficaz.

La principal aportación de este trabajo fue establecer una periodización de los edificios religiosos levantados por indicaciones de los franciscanos de la provincia franciscana de San Pedro y San Pablo de Michoacán, en la época virreinal, que resulta de gran utilidad para comprender, valorar y conservar los edificios que permanecen como testimonio de la labor evangelizadora

100 BCUNAM, “Copia del estado”, fs. 65-66.

101 Sigaut, Catálogo del patrimonio, p. 66. 
en esta parte de lo que fue la Nueva España. De igual manera establece algunas pautas que pueden ser de interés para los historiadores de la orden franciscana y la historia de la arquitectura mexicana.

Nos interesaba averiguar si la actividad constructiva de conventos, capillas y templos impulsados por los franciscanos de la provincia de Michoacán durante el periodo virreinal podía agruparse en etapas, de acuerdo a las estrategias que tenía la orden para la evangelización, adoctrinamiento y administración de sacramentos de dichos pueblos. Evidentemente nos enfrentamos a una falta de información sobre la historia constructiva de la arquitectura religiosa de muchas de las unidades que conformaban la provincia de Michoacán; sin embargo, las crónicas franciscanas, una serie de documentos de archivo, estudios bibliográficos y la observación de los vestigios de la mayoría de los conventos, nos permitieron identificar cinco etapas de la presencia de los frailes menores en la provincia de Michoacán y su actividad constructiva.

En la primera etapa, que nombramos incursión o penetración (1525-1540), los primeros frailes, liderados por fray Martín de Jesús, arribaron a Tzintzuntzan, y desde ahí comenzaron los primeros intentos de evangelizar a los pueblos de la ribera del lago de Pátzcuaro y de unos cuantos asentamientos de la sierra central de Michoacán, para lo cual encomendaron levantar edificios provisionales de materiales efímeros. En la segunda etapa (1540-1570) en el occidente de la Nueva España aumentó el número de religiosos, quienes fundaron pueblos, hicieron congregaciones, levantaron más conventos o renovaron los primitivos e incursionaron en la Tierra Caliente, Jalisco y la Gran Chichimeca. En este periodo también es cuando se levanta la mayoría de hospitales y capillas de la Concepción en los pueblos de indios. Durante la siguiente etapa (1570-1650) se consolida la presencia franciscana y se reconstruye la mayoría de conventos, templos y capillas franciscanos en toda la provincia, pero sobre 
todo se pone atención a los pueblos y villas fundadas al norte del río Lerma, que prosperaban debido a la actividad minera de la zona. La penúltima etapa (1650-1670) se caracterizó por una renovación, ampliación y embellecimiento de templos, conventos y capillas, principalmente en las villas, pueblos y ciudades prósperas de la Gran Chichimeca. La última etapa del virreinato se identifica por los procesos de secularización que afectaron el funcionamiento de una buena parte de doctrinas franciscanas, quedando sólo algunas de ellas en uso, lo que sería el primer golpe para la disminución de poder de las órdenes regulares y la paulatina desaparición y deterioro de la mayoría de sus edificios, no sólo en la provincia de Michoacán sino en toda la Nueva España.

Aunque cada uno de los pueblos y cada una de las unidades religiosas de Michoacán manejadas por los hermanos menores tuvieron sus particularidades, podemos afirmar que existieron procesos generales compartidos que ayudan a ver una historia, sí como un proceso de larga duración, pero también identificar puntos coyunturales, debido en gran parte a que las políticas de la corona española y virreinal, así como los acuerdos que se tomaban en los capítulos generales y provinciales de la orden, determinaban el proceder de los frailes en todo su territorio y muchas veces se reflejaban en la actividad constructiva de su arquitectura. 


\section{Mapa 1}

CONVENTOS, VICARÍAS Y MISIONES DE LA PROVINCIA

FRANCISCANA DE MICHOACÁN DE LA ÉPOCA VIRREINAL

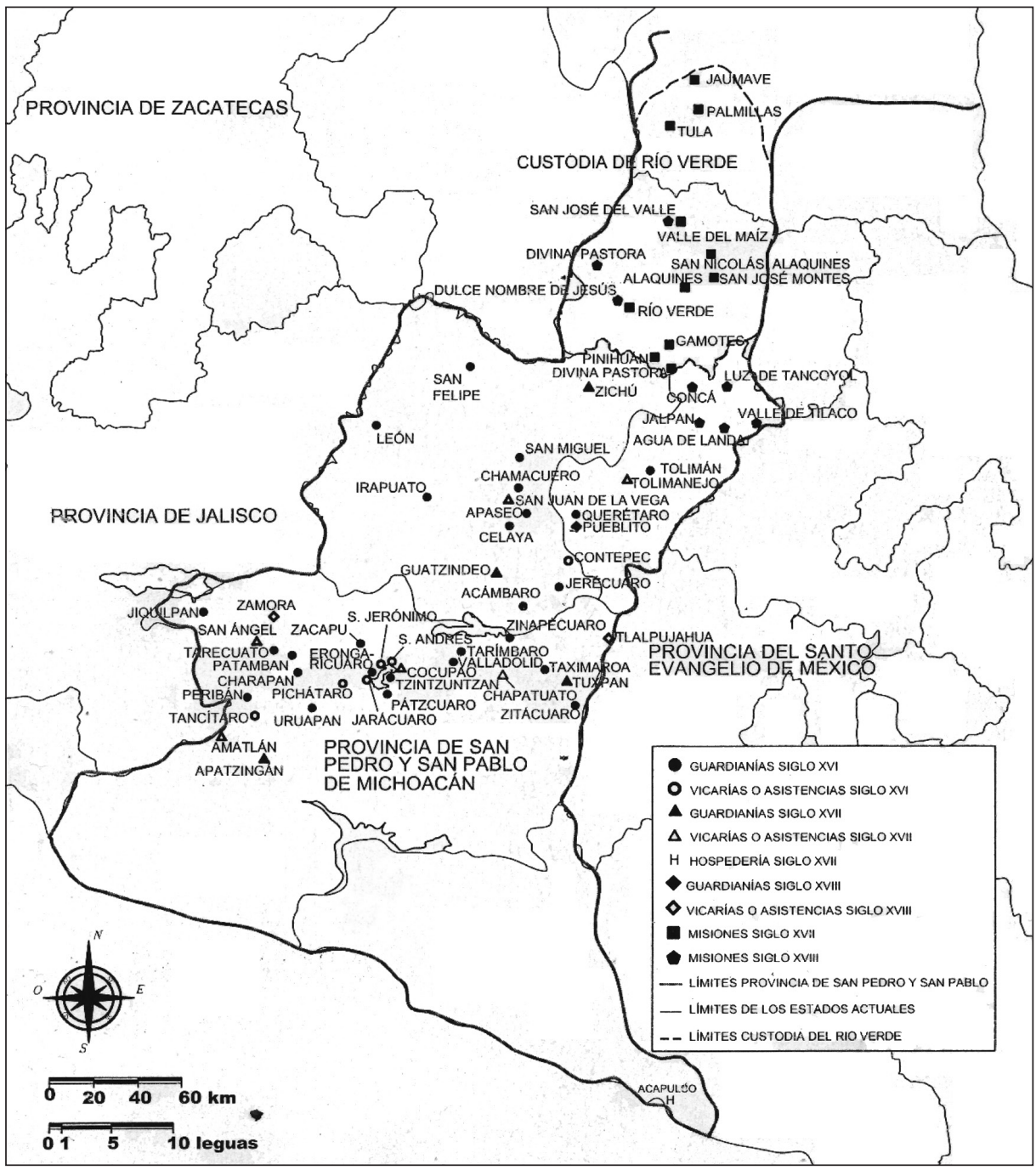

FuENTE: elaboración propia. 


\section{SIGLAS Y REFERENCIAS}

AGN, RCO Archivo General de la Nación, Reales cédulas originales, Ciudad de México, México.

AGN, $H$ Archivo General de la Nación, Historia, Ciudad de México, México.

AGN, $T$ Archivo General de la Nación, Tierras, Ciudad de México, México.

AHCM, D, G, RF Archivo Histórico Casa de Morelos, fondo Diocesano, sección Gobierno, Religiosos Franciscanos.

BC UNAM, FA, E, CF Biblioteca Central de la Universidad Nacional Autónoma de México, fondo Antiguo, Materias eclesiásticas, Conventos de frailes, Ciudad de México, México.

BNAH, $F \quad$ Biblioteca Nacional de Antropología e Historia, fondo Franciscano, México.

BNM, $F$ Biblioteca Nacional de México, fondo Franciscano, Ciudad de México, México.

CEHM Centro de Estudios de Historia de México, Ciudad de México, México.

Alcalá, fray Jerónimo de, La Relación de Michoacán (estudio preliminar y notas de francisco Miranda), Morelia, Fimax Publicistas, 1980.

Anónimo, Conjunto Arquitectónico de la Iglesia de "San Francisco de Asís" y Convento de "Santa María de Gracia", Simbolo de Identidad Religiosa y Cultural de Acámbaro, Gto. Guanajuato, H. Ayuntamiento Constitucional 2015-2018, Dirección de Desarrollo Económico y Turismo y Oficina de la Crónica Municipal, 2018.

Azevedo, Eugenia María (dir.), Del territorio a la arquitectura en el obispado de Michoacán, Morelia, Consejo Nacional de Ciencia y Tecnología, 2008.

Beaumont, Pablo, Crónica de Michoacán, Morelia, Balsal Editores, 1985, 3 tomos.

Becerril Patlán, René e Igor Cerda Farías (comps.), Catálogo de documentos históricos coloniales de Michoacán, Expedientes microfilmados y reproducidos, México, Universidad Michoacana de San Nicolás de Hidalgo, Secretaría de Difusión Cultural y Extensión Universitaria, 2005.

Brading, David, Una iglesia asediada: el obispado de Michoacán 1749-1810, México, Fondo de Cultura Económica, 1994. 
Bravo Ugarte, José, Historia sucinta de Michoacán, Morelia, Morevallado Editores, 1993.

Carrillo Cázares, Alberto, Michoacán en el otoño del siglo XVII, Zamora, El Colegio de Michoacán, Gobierno del Estado de Michoacán, 1993.

Castro Gutiérrez, Felipe, Los tarascos y el imperio español 1600-1740, México, Universidad Nacional Autónoma de México, Universidad Michoacana de San Nicolás de Hidalgo, 2004.

Chanfón Olmos, Carlos (coord.), Historia de la arquitectura y el urbanismo mexicanos, México, Fondo de Cultura Económica, Universidad Nacional Autónoma de México, 2001, 3 volúmenes.

Chauvet, fray Fidel de Jesús, Los franciscanos en México (1523-1980), México, Provincia del Santo Evangelio de México, 1981.

Ciudad Real, Antonio de, Tratado curioso y docto de las grandezas de la Nueva España. Relación breve y verdadera de algunas cosas de las muchas que sucedieron al Padre fray Alonso Ponce [...], México, Josefina García y Víctor M. Castillo editores, 1976, 2 volúmenes.

Cruz, Antonio, et al., Indios y franciscanos en la construcción de Santiago Querétaro (siglos XVI y XVII), México, Gobierno del Estado de Querétaro, 1997.

Cuevas, Mariano, Historia de la Iglesia en México, México, Porrúa, 1992, 2 tomos.

Escandón Bolaños, Patricia, "La provincia franciscana de Michoacán en el siglo xviı", tesis de doctorado en historia, México, Universidad Nacional Autónoma de México, 1999.

Escobar, fray Mathías de, Americana Thebaida, Morelia, Universidad Michoacana de San Nicolás de Hidalgo, Morevallado Editores, 2008.

Espinosa, Isidro Félix de, Crónica de la provincia franciscana de los apóstoles San Pedro y San Pablo de Michoacán, Morelia, Universidad Michoacana de San Nicolás de Hidalgo, Morevallado Editores, 2003.

Florescano, Enrique (coord.), Historia general de Michoacán, Morelia, Gobierno del Estado de Michoacán, Instituto Michoacano de Cultura, 1989, vol. 1. 
Font FrAnsi, Jaime, "Desarrollo y consolidación del conjunto conventual de San Francisco de la ciudad de Santiago Querétaro durante el siglo XvII", en Cruz et al., 1997, pp. 221-284.

Gerhard, Peter, "Congregaciones de indios en la Nueva España antes de 1570”, en Historia Mexicana, xxvi: 3 (103) (ene.-mar. 1977), pp. 347-395.

Gerhard, Peter, Geografía histórica de la Nueva España 1519-1821, México, Universidad Nacional Autónoma de México, 1986.

GonzÁLez, Jorge René, Estructura, organización y vida cotidiana de los Colegios Apostólicos de Propaganda Fide, siglo XVIII, México, Instituto Nacional de Antropología e Historia, 2009.

Hernández Téllez, Mahler, "El convento de Nuestra Señora de la Asunción de Erongarícuaro, 1547-1761”, tesis de maestría en historia, Morelia, Universidad Michoacana de San Nicolás de Hidalgo, 2011.

Kubler, George, Arquitectura mexicana del siglo XVI, México, Fondo de Cultura Económica, 1948.

La Rea, Alonso, Crónica de la orden de Nuestro Seráfico Padre San Francisco Provincia de San Pedro y San Pablo de Michoacán en la Nueva España, México, La voz de México, 1982.

León Alanís, Ricardo, Los orígenes del clero y la Iglesia en Michoacán, 15251640, Morelia, Universidad Michoacana de San Nicolás de Hidalgo, 1997.

López Tejeda, Florencio, La Universidad Real y Pontificia de Celaya, Celaya, Consejo Consultivo Editorial del Bajío, 2008.

Martínez, José Manuel, "Las cofradías novohispanas de Tzintzuntzan. Bienes, prácticas y espacios de devoción”, en Relaciones. Estudios de Historia y Sociedad, 51 (2017), pp. 11-57.

Martínez Baracs, Rodrigo, “Los inicios de la evangelización”, en FloresCANO (coord.), 1989, vol. 1.

Martínez-López Cano, Pilar (coord.), La Iglesia en Nueva España. Problemas y perspectivas de investigación México, Universidad Nacional Autónoma de México, 2010. 
Mazín Gómez, Óscar (preparación y estudio), El Gran Michoacán. Cuatro informes del obispado de Michoacán 1759-1769, Zamora, El Colegio de Michoacán, Gobierno del Estado de Michoacán, 1986.

Mazín Gómez, Óscar, "Secularización de parroquias en el antiguo Michoacán”, en Relaciones, 26 (1986), pp. 23-34.

Mendieta, fray Jerónimo de, Historia eclesiástica indiana, México, Porrúa, 1990.

Morales, Francisco, "Los franciscanos en la Nueva España. La época de oro, siglo xvı”, en Morales (ed.), 1983.

Morales, Francisco (ed.), Franciscan Presence in the Americas. Essays on the Activities of the Franciscan Friars in the Americas, 1492-1900, Maryland, Academy of American Franciscan History, 1983.

Paredes, Carlos, et al., Michoacán en el siglo XVI, Morelia, Fimax Publicistas, 1984.

Paso y Troncoso, Francisco del (recop.), Epistolario de la Nueva España, 1505-1818, vol. 8, México, Antigua Librería Robredo, 1939.

Ramírez Montes, Mina, La catedral de Vasco de Quiroga, Zamora, El Colegio de Michoacán, 1986.

Rangel, José Alfredo, "Pames, franciscanos y estancieros en Río Verde, Valles y sur de Nuevo Santander, 1600-1800”, en Relaciones, 120 (2009), pp. 225-266.

Ricard, Robert, La conquista espiritual de México, México, Fondo de Cultura Económica, 1992.

Rubial García, Antonio, "Las órdenes mendicantes evangelizadoras en Nueva España y sus cambios estructurales durante los siglos virreinales", en Martínez- López Cano (coord.), 2010.

Salazar González, Guadalupe, "Ordenamiento espacial del territorio en el antiguo obispado de Michoacán”, en Azevedo (dir.), 2008.

Sigaut, Nelly, Catálogo del patrimonio arquitectónico del Bajío zamorano, Zamora, El Colegio de Michoacán, 1991. 
Tello, fray Antonio, Crónica miscelánea de la Sancta Provincia de Jalisco (libros quinto y sexto), México, Gobierno del Estado de Jalisco, Universidad de Guadalajara, Instituto Cultural Cabañas, 1987.

Warren, J. Benedict, La conquista de Michoacán 1521-1530, Morelia, Fimax publicistas, 1977.

WRIGHT, David Charles, Los franciscanos y su labor educativa en la Nueva España (1523-1580), México, Instituto Nacional de Antropología e Historia, Universidad del Valle de México, 1998.

Zavala, Silvio, El servicio personal de los indios en la Nueva España, 15211550, t. 1, México, El Colegio de México, El Colegio Nacional, 1984. 
